\author{
Мунтян I.B. \\ кандидат соціологічних наук, асистент \\ кафедра соціології, фрілософії і права \\ Одеська національна академія харчових технологій \\ вул. Канатна, 112, м. Одеса, Україна, 65039 \\ E-mail: Irina070885@gmail.com
}

\title{
ОСОБЛИВОСТІ ТА ПЕРСПЕКТИВ РОЗВИТКУ РИНКУ РЕКЛАМИ В УКРАÏHI
}

В статті досліджуються сучасні тенденції українського рекламного ринку. Виявлено, що серед найбільш впливових та пріоритетних каналів рекламних комунікацій залишаються Інтернетреклама та реклама на телебаченні. Окреслені види та дана характеристика ролей реклами. Досліджені основні засоби реклами, за допомогою яких вона доходить до споживача. На основі статистичних даних окреслені їх переваги та недоліки. Представлений аналіз та прогноз тенденцій розвитку українського рекламного ринку в у мовах політичної та соціально-економічної кризи. Робиться висновок, що сучасний український рекламний сектор вимагає якісного наукового підходу щодо організації та управління рекламного ринку, налагодження ефективної, рекламної діяльності, яка гарантувала б суб'єктам рекламного сектору якісний, конкурентоспроможний рекламний продукт.

Ключові слова: комплекс маркетингових комунікацій, реклама, ринок реклами, рекламна діяльність, тенденції розвитку ринку реклами.

This work is licensed under a Creative Commons Attribution 4.0 International License http://creativecommons.org/licenses/by/4.0/

Постановка проблеми та її зв'язок з важливими науковими та практичними завданнями. Активна трансформація українського суспільства на основі ринкових відносин, зміни кон'юнктури ринку обумовили стрімкий розвиток рекламної діяльності. Сьогодні можна стверджувати про існування соціально-економічного простору, створеного на основі реклами, в якому становиться та активно розвивається досить розвинена система економічних, соціокультурних, соціальних, правових відносин між основними суб'єктами цього простору - рекламодавцями, виробниками, розповсюджувачами і споживачами реклами.

Характерною особливістю реклами останніх двох-трьох десятиліть $є$ перетворення їі в окрему галузь економіки країни, а саме рекламний бізнес. Рекламний бізнес настільки потужно i швидко розвивається, що за темпами і якісних зрушень значно випереджає багато інших сфер виробничоекономічного життя суспільства. Саме в рекламному бізнесі спостерігаються на даному етапі висока концентрація i централізація капіталу. Значною мірою він акумулюється в найпотужніших компаніях 3MI, а також у світових лідерів рекламного бізнесу міжнародних рекламних агентствах і їх асоціаціях. Спостерігається тенденція великих інвестицій в засоби масової інформації безпосередньо великими промисловими і торговими компаніями.

Реклама як одна із складових маркетингових комунікацій безпосередньо залежить від загальноекономічної ситуації в країні, тому комунікаційна активність на ринку іноді розглядається як своєрідний ін- дикатор економічного розвитку. Сьогодні Україна переживає нелегкі часи: нестабільна політична ситуація в країні, соціально-економічна криза, військовий конфлікт на Сході, передвиборча кампанія, інфляція наклади суттєвий відбиток на особливості розвитку ринку реклами. Враховуючи ці факторі постає питання дослідження сучасних тенденцій розвитку реклами та перспектив її подальшого розвитку.

Аналіз останніх публікацій по проблемі. Реклама як основний елемент маркетингу виступала предметом досліджень як зарубіжних, так і українських дослідників, зокрема у роботах: Д. Бернета, С. Моріарті [1], Ф. Котлера, Ф. Тріаса де Без [2], П. Сміта, К. Беррі, А. Пулфорда [3], Е. Гріна [4], Дж. Девіса [5], М. Хьюмана, Р. Тенсі, Дж. Кларк [6], В.Л. Музиканта [7], І.О. Пойти [8], Г.А. Рижкової [9], T.О. Примак [10], Н.М. Грицюта [11] та ін.

Формулювання цілей дослідження. Аналіз та прогноз тенденцій розвитку українського рекламного ринку в у мовах політичної та соціально-економічної кризи.

Виклад основних результатів та їх обгрунтування. Сьогодні реклама $є$ предметом дослідження багатьох дисциплін, зокрема, економіки, соціології, історії, правознавства журналістики. Все це обумовлює наявність різних підходів щодо інтерпретації поняття «реклама». До того ж існує чимало дефініцій зарубіжних дослідників, особливо американської та західноєвропейської школи. Всі вони мають право на існування, однак наявні визначення обумовлюють складність визначення предмету вивчення. Аналіз 
дефініцій показує, що практично всі автори визначають рекламу як певну форму масової комунікації й звертають увагу на характер рекламної комунікації і iii вплив на масову та індивідуальну свідомість.

У науковому колі дослідники, вивчаючи феномен реклами, у більшості випадків пов'язують іiі сутність із маркетинговою діяльністю. У сучасному суспільстві реклама виступає важливим інструментом маркетингу, будучи одним із основних елементом маркетингових комунікацій. Однак, зважаючи на ті глобалізаційні процеси, які сьогодні відбуваються у світі, слід звернути увагу на більш масштабний вплив реклами, яка стала провідником міжкультурного діалогу, який відбувається на рівні різних культур. ÏÏ сутність може бути розглянута з точки зору тих ролей, які вона відіграє у суспільному житті.

Рекламу і проблему іiі ефективності необхідно аналізувати в широкому соціокультурному контексті. Реклама виконує різноманітні соціальні функції: комерційну, символічну, компенсаторну, еталоннонормативну, психологічну. Розглядаючи рекламу як особливий вид комунікації, можна простежити, як в ній виявляються три сторони, властиві процесу спілкування: інформаційна, перцептивна, інтерактивна. Слід зазначити, що ii інформаційна сторона має не тільки комерційний характер. Реклама містить важливу соціальну інформацію, пов'язану 3 процесом соціокультурної ідентифікації - належність до групи, спільноти, прихильність до певного стилю життя, цінностей культури. У сучасному суспільстві, коли інтенсивно відбуваються процеси соціальної мобільності, в тому числі і вгору по соціальних сходах, споживачі можуть потребувати навчанні нових зразків споживчої поведінки. Реклама виконує роль соціально-економічного орієнтування - це стосується товарів i марок, відповідних новому соціальному статусу. Рекламна комунікація, використовуючи певні цінності та норми, безумовно, має вплив на формування та розвиток споживчих переваг суспільства. Таким чином, рекламу можна розглядати як один із факторів формування однорідних цінностей споживачів, які призводять до стабілізації соціального середовища.

Сьогодні у динаміці розвитку реклами спостерігається активний перехід від класичних форм реклами до більш сучасних методів впливу на аудиторію споживачів. Ця тенденція обумовлено багатьма факторами, зокрема, розвитком сучасних технологій, сучасним стилем життя людей, зміною цінностей суспільства та ін. Саме тому на сучасному ринку реклами потрібно мати на увазі те, що інструменти, які використовувалися раніше будуть не так ефективні або зовсім неефективні в даний період часу. Для того аби виділити основні тенденції розвитку реклами, необхідно виокремити основні її види.

Реклама диференціюється за наступними ознаками:

- спрямованість на аудиторію: реклама споживчих товарів; бізнес-реклама - реклама обладнання, послуг у сфері виробництва; торгова реклама оптовикам; реклама 3 метою переконати професіоналів в необхідності закупівлі рекламованого обладнання, підтримки престижу професії;

- широта охоплення території: міжнародна реклама, спрямована на зарубіжні ринки; національна реклама, націлена на вітчизняний споживчий ринок; регіональна реклама, призначена для певної області регіону; місцева реклама, розрахована на споживачів, які мешкають у даному місті чи районі;

- цільове призначення: реклама товарів і послуг, що поліпшують збут; реклама товарів повсякденного попиту та реклама промислових товарів; реклама ідей; комерційна реклама, спрямована на отримання прибутку в найближчій чи віддаленій перспективі; некомерційна реклама (наприклад, реклама благодійних фондів та інших громадських організацій); реклама-дія, тобто реклама, що спонукає клієнта придбати певний товар за купони, що дають право на знижку при його покупці [7].

Також доречно звернути увагу на засоби реклами, адже саме за допомогою них реклама надходить до споживача. Від правильного обрання засобів реклами залежить успіх всієї рекламної кампанії товару або послуги [8]. Кожен із цих засобів має свої переваги та недоліки, тому важливим $є$ ретельний підхід до того засобу, який буде найоптимальнішим для просування конкретного товару. Виділяють такі основні засоби реклами:

1. Реклама на телебаченні виступає одним із досконалих каналів трансляції рекламного повідомлення. На рекламному ринку саме телебачення займає пріоритетні позиції, оскільки має вплив на більш широку аудиторію, надаючи більш широкі комунікаційні можливості порівнюючи з іншими каналами розповсюдження реклами. Телевізійна комунікація має безпосередній прямий контакт на аудиторію, досягаючи ефект присутності. Саме тому найбільші рекламні кампанії України віддають перевагу саме цьому каналу розповсюдження реклами. Незважаючи на свої переваги телевізійна реклама має чимало недоліків, серед яких високі ціни за виготовлення рекламного ролика та ефірний час телебачення, короткометражність реклами, негативне ставлення глядачів щодо реклами, яка перериває перегляд програм, серіалів і т.д.

За даними Всеукраїнської рекламної коаліції (ВРК) обсяг телевізійної реклами у 2018 році збільшився на 26\% порівняно з 2017 роком [12]. Експерти прогнозують подальшу позитивну тенденцію щодо даного засобу трансляції реклами, за прогнозами експертів ВРК у 2019 році передбачається збільшення обсягу телевізійної реклами на 24\% [12].

2. Реклама у пресі - може охоплювати досить значну аудиторію, вона може потрапляти майже у всі сегмента суспільства. Через відносну дешевизну цей вид засобів реклами користується широким попитом серед рекламодавців, особливо тих, кому не по кишені трансляція реклами на телебаченні. Важливо також зазначити, що реклама у пресі не викликає такої роздратованості аудиторії, як наприклад, на телебаченні або мережі Інтернет. Серед недоліків реклами серед виділити наступні: неякісний друк реклами, короткий період використання, виключення із аудиторії спожи- 
вачів молодих людей, які надають перевагу іншим засобам масової інформації та ін. Згідно інформації ВРК у 2018 році обсяг реклами у пресі збільшився майже на $19 \%$, однак у поточному році цей показник у незначній мірі знизиться[12].

3. Радіо-реклама є засобом негайного вливу, який може охоплювати певний сегмент аудиторії протягом 24 годин на добу. Сила уваги до радіореклами безпосередньо залежить від іiї тривалості. Ефективна радіореклама повинна пробитися крізь завісу інших радіо оголошень і дійти до свідомості слухача. Однак сьогодні швидке зростання конкуруючих радіостанцій призвело до їх перевантаженості рекламою. У 2018 році темпи збільшення обсягу радіореклами майже в однаковому співвідношенні 3 пресою і склали лише 19\%, проте у 2019 р. спостерігатиметься тенденція його зростання [12].

4. Зовнішня реклама - засіб реклами, який розрахований переважно на візуальне сприйняття. Він досить активно використовується на ринку реклами як в Україні, так і в світі. Оцінюючи засоби зовнішньої реклами до їі переваг слід віднести широкий обсяг аудиторії, значну кількість рекламних контактів, довготривалість впливу на аудиторію та ін. Однак для цього засобу реклами характерні складності із оформленням необхідного пакету документі для встановлення конструкцій, незначний обсяг інформації щодо рекламуємого товару, послуги, відносна висока вартість виготовлення та розміщення реклами та iн.

Варто зазначити, що зовнішня реклама $є$ досить розповсюдженим засобом презентації реклами, про що свідчить статистичні дати про обсяги їі використання. Так, у 2018 році обсяг зовнішньої реклами зріс на 29\%, однак, як прогнозують експерти Всеукраїнської рекламної коаліції у поточному році ця тенденція знизиться до 23\% [12]..

5. Друкована реклама (каталоги, брошури, проспекти) - засіб реклами, який доволі часто використовується в ході важливих ділових зустрічей, презентацій, виставок. Ця реклама характеризується оперативністю подачі, достовірністю та повнотою інфо- рмації, ймовірність швидкого зворотнього зв'язку 3 аудиторією. Основним недоліком друкованої реклами $\epsilon$ відсутність аудіо зв'язку з потенційними споживачами. Іноді візуальний контакт не надає належної дії, а при відсутності звукового супроводу і зовсім не викликати інтерес у споживачів.

6. Інтернет-реклама - розглядаючи актуальність використання інтернет-реклами у міжнародному просторі, ігнорувати цей вид реклами просто неможливо, адже завдяки мережі Інтернет відкривається можливість швидкої та дешевої інтеграції на міжнародний ринок. Інтернет забезпечує безпосередній прямий продаж. Цей вид реклами має вплив на аудиторію протягом 24 годин, знайомлячи потенційних клієнтів з рекламуємою продукцію. При виготовленні інтернет-реклами використовуються яскраві кольори, відеоролики та звук, що забезпечує більш швидке засвоєння інформації. Важливою перевагою інтернетреклами $є$ можливість отримання точних статистичних даних про кількість споживачів, які вступили в контакт із продавцем. Можна впевнено стверджувати, що цей вид реклами й надали буде широко використовуватися і активно розвиватися. У 2019 році експерти прогнозують досить інтенсивне зростання використання Інтернет реклами до з $17 \%$ до 50\% у порівнянні з 2018 роком [12].

Як зазначають дослідники національної реклами ринок комунікацій в Україні залишається на сьогодні непрозорим, тому офіційних даних щодо його обсягів не існує. Серед найбільш авторитетних та об'єктивних кампаній, які презентують експертні оцінки 3 розвитку ситуації на ринку комунікацій, Українська Рекламна Асоціація(УРА) та Українська Асоціація Маркетингу (УАМ).

У таблиці 1 наведені статистичні дані про обсяги комунікаційних послуг, виконаних українськими компаніями протягом минулих двох років, та прогноз на поточний 2019 рік. Представлені показники отримані шляхом узагальнення результатів досліджень ринку маркетингових комунікаційних послуг різними організаціями, зокрема УРА; УАМ [12].

Таблиця 1

Обсяг комунікаційних послуг в Україні [12]

\begin{tabular}{|l|c|c|c|c|c|}
\hline & $\begin{array}{c}\text { Підсумки } \\
\mathbf{2 0 1 7} ., \\
\text { млн. грн. }\end{array}$ & $\begin{array}{c}\text { Підсумки } \\
\mathbf{2 0 1 8 p . ,} \\
\text { млн. грн. }\end{array}$ & $\begin{array}{c}\text { Відсоток змін } \\
\mathbf{2 0 1 8} \text { до 2017 }\end{array}$ & $\begin{array}{c}\text { Прогноз на } \\
\mathbf{2 0 1 9} \text { р., } \\
\text { млн. грн. }\end{array}$ & $\begin{array}{c}\text { Відсоток змін } \\
\mathbf{2 0 1 9} \text { до 2018 }\end{array}$ \\
\hline ТВ-реклама, всього & 7329 & 9269 & $26 \%$ & 11526 & $24 \%$ \\
\hline Реклама в пресі, всього & 1355 & 1612 & $18,9 \%$ & 1843 & $14,4 \%$ \\
\hline Радіо реклама, всього & 480 & 578 & $20 \%$ & 715 & $24 \%$ \\
\hline Зовнішня реклама & 2263 & 2923 & $29 \%$ & 3601 & $23 \%$ \\
\hline Indoor реклама & 102 & 127 & $24 \%$ & 152 & $20 \%$ \\
\hline $\begin{array}{l}\text { Digital (Internet) Медіа } \\
\text { реклама }\end{array}$ & 2145 & 2520 & $17 \%$ & 3772 & $50 \%$ \\
\hline $\begin{array}{l}\text { Всього рекламний медіа } \\
\text { рынок }\end{array}$ & 14041 & 17520 & $25 \%$ & 22221 & $27 \%$ \\
\hline
\end{tabular}

Варто окреслити ті тенденції, які сьогодні відбуваються на ринку реклами. Характерною особли- вістю сучасного ринку реклами $є$ його перенасиченість. Реклама сьогодні нав'язується споживачу, що, 
безумовно, викликає певну реакцію - обурення, роздратованість, відразу і т.д. Однієї із гострих проблем сфери реклами $\epsilon$ те, що сюжетна лінія багатьох реклам є однотипною. Як наслідок, перед розробниками реклами актуальним стає питання розробки реклами зовсім нового формату, без нав'язливих настроїв і в той же час цікавою, привабливою для аудиторії споживачів. Для цього необхідно кардинально змінити концепцію презентації реклами, використовувати інші методи щодо її розробки.

Серед гострих проблем ринку реклами тенденція зниження ефективності реклами на телебаченні та друкованих засобах масової інформації. Як свідчать статистичні звіти рекламних кампаній сьогодні телевізійна реклама не користується такою популярністю, як то було раніше. Із розширенням впливу мережі Інтернет кількість його користувачів невпинно зростає, що, безумовно, впливає на ефективність інших засобів презентації реклами.

Динамічний розвиток мережі Інтернет можна вважати одним із найголовніших подій в світі реклами за останні роки. Інтернет-простір відкрив перспективну платформу для розвитку для реклами. Інтернет змінив основні методи впливу на аудиторію споживачів, започаткував нові правила, стандарти комунікації, які відбуваються на інтернаціональному рівні. Однією 3 головних переваг віртуального простору, як платформи для впливу на споживача, $є$ можливість персонального впливу на людину, надаючи інформацію про їі стать, вік, місцезнаходження та ін.

Висновки та перспективи подальших досліджень. Незважаючи на складну політичну ситуацію країни, соціально-економічну кризу, сьогодні реклама в Україні виходить на новий рівень. Ця тенденція зберігатиметься й надалі, але зі збільшенням розмірів маркетингових бюджетів рекламодавців. Як свідчить сучасна практика, інноваційні рекламні технології впливу на споживача впевнено займають лідируючі позиції на рекламному ринку. Серед найбільш впливових та пріоритетних каналів рекламних комунікацій залишаються Інтернет-реклама та реклама на телебаченні, які активно продовжують розвиватися та поширювати вплив на аудиторію. Немедійні рекламні комунікації втрачають свої колись пріоритетні позиції, що є наслідком глобалізаційних процесів, стрімкого розвитку інформаційного простору та змін переваг акторів рекламного ринку. Сьогодні серед актуальних проблем сфери реклами $є$ питання представлення якісного рекламного продукту, недосконалість діючого законодавства, низький рівень державного управляння та контролю у рекламному секторі, відставання від новітніх тенденцій, які сьогодні активно впроваджуються у розвинутих країнах світу, необхідність збільшення кількості спеціалістів з галузі реклами та ін. Всі ці питання повинні завжди бути у центрі уваги об'єктивних науково-методичних досліджень, результати яких стануть підгрунтям розробки стратегії якісного оновлення вітчизняного рекламного бізнесу. Сучасний український рекламний сектор вимагає якісного наукового підходу щодо організації та управління рекламного ринку, налагодження ефективної, рекламної діяльності, яка гарантувала б суб'єктам рекламного сектору якісний, конкурентоспроможний рекламний продукт.

Зростаюча тенденція впливу PR-фахівця на сучасне інформаційне суспільство передбачає вивчення його соціокультурного портрету, а також визначення актуальних проблем 3 професійної етики фахівців зі зв'язків з громадськістю, що є перспективою подальших досліджень у даному напрямку.

\section{Література}

1. Бернет Д. Маркетинговые коммуникации. Интегрированный подход / Бернет Д., Мориарти С.; пер. с англ. Н. Габенов, В. Кузин. СПб., 2001. 860 с.

2. Котлер Ф. Новые маркетинговые технологии: Методики создания гениальных идей / Котлер Ф., Триас де Без Ф.; пер. с англ. Т.В. Виноградова, Л.Л. Царук; ред. пер. Т.Р. Тэор. СПб., 2004. 190 с.

3. Сміт П. Комунікації стратегічного маркетингу / Сміт П., Беррі К., Пулфорд А.; пер. 3 англ. під ред. проф. Л.Ф. Нікуліна. К., 2001. С.48-49.

4. Грин Э. Креативность в паблик рилейшнз / Грин Э.; пер. с англ. В. И. Писарева. СПб., 2003. 222 с.

5. Дэвис Дж. Исследования в рекламной деятельности: Теория и практика. М.: ИД «Вильямс», 2003.

$864 \mathrm{c}$.

6. Hyman M. R., Tansey R., Clark J.W. Research on Advertising Ethics: Past, Present, and Future // Journal of Advertising. 1994. Vol. 23. No. 3. P. 5-15.

7. Музыкант В.Л. Реклама в действии: история, аудитория, приемы. М.: Эксмо, 2006. 240 с.

8. Пойта I.О. Проблеми та перспективи ринку реклами у системі інструментарію маркетингу // Економіка. Управління. Інновації: електрон. наук. фах. вид. 2017. № 1.

9. Рижкова Г.А. Особливості і перспективи розвитку ринку маркетингових комунікацій в Україні // Економічний Нобелівський вісник. 2014. № 1 (7). С. 375-380. $2001.384 \mathrm{c}$

10. Примак Т.О. Маркетингові комунікації в системі управління підприємством. К.: ООО «Експерт»,

11. Грицюта Н.М. Етика реклами як естимаційний орієнтир сучасного суспільства : монографія. К. : Інт журналістики, 2012. 416 с.

12. Объем рекламного рынка Украины 2018 г. и прогноз объемов рынка 2019 г. Экспертный прогноз Всеукраинской рекламной коалиции: веб-сайт. URL: http://mmr.ua/show/obiem_reklamnokommunikatsionnogo_rynka_ukrainy_2018_i_prognoz_obiemov_rynka_2019 (дата звернення: 01.02.2019). 


\author{
Мунтян И.В. \\ кандидат социологических наук, ассистент \\ кафедра социологии, философии и права \\ Одесская национальная академия пищевых технологий \\ ул. Канатная, 112,г. Одесса, Украина, 65039 \\ E-mail:Irina070885@gmail.com
}

\title{
ОСОБЕННОСТИ И ПЕРСПЕКТИВЫ РАЗВИТИЯ РЫНКА РЕКЛАМЫ В УКРАИНЕ
}

\begin{abstract}
В статье исследуются современные тенденции украинского рекламного рынка. Инновационные рекламные технологии воздействия на потребителя уверенно занимают лидирующие позиции на рекламном рынке. Установлено, что среди наиболее влиятельных и приоритетных каналов рекламных коммуникаций остаются Интернет-реклама и реклама на телевидении, которые активно продолжают развиваться и распространять влияние на аудиторию. Вместе с тем Интернет-реклама развивается более динамично, поскольку, Интернет-пространство открывает перспективную платформу для развития для рекламы. Интернет изменил основные методы воздействия на аудиторию потребителей, начал новые правила, стандарты коммуникации, которые происходят на международном уровне. Представленные результаты исследования свидетельствуют о том, что немедийные рекламные коммуникации теряют свои некогда приоритетные позиции, что является следствием глобальных процессов, стремительного развития информационного пространства и изменений преимуществ и предпочтений актеров рекламного рынка. Указаны виды и дана характеристика ролей рекламы. Исследованы основные средства рекламы, с помощью которых она доходит до потребителя. На основе статистических данных очерчены их преимущества и недостатки. Установлено, среди острых проблем рекламной сфреры - некачественная рекламная продукция, низкий уровень предоставляемых услуг рекламодателями, несовершенный механизм правового регулирования отношений в сфере рекламы. Представлен анализ и прогноз тенденций развития украинского рекламного рынка в условиях политического и социально-экономического кризиса. Делается вывод, что современный украинский рекламный сектор требует качественного научного подхода к организации и управлению рекламного рынка, налаживание эффективной, рекламной деятельности, которая гарантировала бы субъектам рекламного сектора качественный, конкурентоспособный рекламный продукт.
\end{abstract}

Ключевые слова: комплекс маркетинговых коммуникаций, реклама, рынок рекламы, рекламная деятельность, тенденции развития рынка рекламы.

\author{
Muntian I. \\ Ph.D., Assistant \\ Department of Sociology, Philosophy and Law \\ Odessa National Academy of Food Technologies \\ Kanatna str., 112, Odesa, Ukraine, 65039 \\ E-mail: Irina070885@gmail.com
}

\section{THE FEATURES AND PERSPECTIVES OF DEVELOPMENT OF THE ADVERTISING MARKET IN UKRAINE}

In the article the analysis of the modern tendencies of the Ukrainian advertising market has been made. Innovative advertising technologies of influence on the consumers and hold the leading positions confidently on the advertising market. It was found that among the most influential and preferred channels of advertising communications are Internet advertising and advertising on television, that actively continue to develop and spread influence on the audience. It is important to note that online advertising is growing more rapidly, because the Internet provides a promising platform for development of advertising. The Internet has changed the basic methods of influence on the audience of consumers, established new rules, standards of communication especially on the international level. The presented results of the research indicate that non-media advertising communications are losing their priority positions. Such situation is the result of global processes, rapid development of the information space and changes in the preferences of the actors of the advertising market. The article shows the types and characteristics of role of advertising. The main advertising media with which it reaches the consumer are investigated. Their advantages and disadvantages based on the statistical data are outlined. It was found that among the actual problems of advertising are low quality promotional products, a low level of services of advertisers, imperfect mechanism of legal regulation of relations in the sphere of advertising. In the article the analysis and prognosis of the tendencies of development of Ukrainian advertising market in terms of political and 
socio-economic crisis have been represented. It is concluded that modern Ukrainian advertising sector requires a qualitative scientific approach to the organization and management of the advertising market. That scientific approach will establish effective promotional activities that would guarantee the subjects of the advertising sector high-quality, competitive promotional product.

Key words: complex of marketing communications, advertising, advertising market, promotional activities, the development trends of advertising market.

\section{References}

1. Bernet, D., Moriarti, S., \& Kuzin, V. (2001). Marketingovyie kommunikatsii. Integrirovannyiy podhod(N. Gabenov, Trans.). SPb.

2. Kotler, F., Trias de Bez, F., \& Tsaruk, L. L. (2004). Novyie marketingovyie tehnologii: Metodiki sozdaniya genialnyih idey (T. V. Vinogradova, Trans.). SPb.

3. Smit, P., Berri, K., \& Pulford, A. (2001). Komunikatsii stratehichnoho marketynhu (L. F. Nikulin, Trans.). Kiev.

4. Grin, E. (2003). Kreativnost v pablik rileyshnz (V. I. Pisareva, Trans.). SPb.

5. Devis, Dzh. (2003). Issledovaniya v reklamnoy deyatelnosti: Teoriya i praktika. Moscow: ID «Vilyams».

6. Hyman, M. R., Tansey, R., \& Clark, J. W. (1994). Research on Advertising Ethics: Past, Present, and Future. Journal of Advertising, 23(3), 5-15.

7. Muzyikant, V. L. (2006). Reklama v deystvii: Istoriya, auditoriya, priemyi. Moscow: Eksmo.

8. Poita, I. O. (2017). Problemy ta perspektyvy rynku reklamy u systemi instrumentariiu marketynhu. Ekonomika. Upravlinnia. Innovatsii, (1).

9. Ryzhkova, H. A. (2014). Osoblyvosti i perspektyvy rozvytku rynku marketynhovykh komunikatsii v Ukraini. Ekonomichnyi Nobelivskyi Visnyk, (1 (7)), 375-380. «Ekspert».

10. Prymak, T. O. (2001). Marketynhovi komunikatsii v systemi upravlinnia pidpryiemstvom. Kiev: OOO nalistyky.

11. Hrytsiuta, N. M. (2012). Etyka reklamy yak estymatsiinyi oriientyr suchasnoho suspilstva. Kiev: In-t zhur-

12. Ob'em reklamnogo ryinka Ukrainyi 2018 g. i prognoz ob'emov ryinka 2019 g. Ekspertnyiy prognoz Vseukrainskoy reklamnoy koalitsii. (2018). Retrieved February 01, 2019, from https://mmr.ua/show/obiem_reklamnokommunikatsionnogo_rynka_ukrainy_2018_i_prognoz_obiemov_rynka_2019

Received 5 February 2019

Approved 19 February 2019

Available in Internet 19.03.2019

Цитування згідно ДСТУ 8302:2015

Мунтян І.В. Особливості та перспективи розвитку ринку реклами в Україні // Економіка харчової промисловості. 2019. Т.11, вип. 1. С. 89-94; doi: 10.15673/fie.v11i1.1299

Cite as APA style citation

Muntian I. (2019). The features and perspectives of development of the advertising market in Ukraine. Food Industry Economics, 11(1), 89-94; doi: 10.15673/fie.v11i1.1299 